\title{
HETEROTRANSPLANTATIONS AND GENOMIC IN CANCER RESEARCH
}

\author{
Michel Leclerc \\ Immunology of Invertebrates \\ Department of Cell Biology, Developmental Biology, Immunology \\ University of Orleans, France \\ E-mail: mleclerc45@gmail.com
}

\begin{abstract}
We performed, in 1975, the first heterotransplantation of invertebrate A.O in nude mouse, then a double heterotransplantation of human tumor and Axial organ next to this last one, always in nude mouse: The human tumor was rejected in $50 \%$ of observed cases. Some

years later, we found that A.O cells exerted an induced and spontaneous cytotoxicity against SP2 and MBL2 mouse tumoral cells.Recently, we discovered a sea star Igkappa gene with immune properties. This gene was inserted in a CMV(cytomegalovirus) and finally in a plasmid called «young » plasmid.

The induced «young » protein exerted a spontaneous cytotoxicity against osteosarcom cells (U2oS cells) against A-375 melanome cells and Hela cells

\section{INTRODUCTION}

In 1975, Leclerc transplanted with success an invertebrate organ: the sea star axial organ(a primitive lymphoïd organ) in nude mouse (1) then risked a double heterotransplantation always in nude mouse: it was composed of a sea star axial organone and a human tumor skin one besides the precedent one, under the skin of nude mouse, in back position.(Unpublished results) In 1983, Luquet and Leclerc (2) shown that the axial organ cells (AO cells), exerted a spontaneous and induced cytotoxicity against mouse SP2 myeloma cells and MBL2 cells.

The AO cells included essentially lymphocytes and phagocytes(1)

40 years later, we discovered a sea star Igkappa gene (3), with immune properties (4) We have studied the behaviour of the «young » protein secreted by the sea star Igkappa gene, in front of human malignant :A-375 melanome cells, human Osteosarcome cells (U2oS cells) and human malignant cells Hela, by the use of plasmids .
\end{abstract}

\section{Animals}

\section{MATERIALS AND METHODS}

a)Asterias rubens, a sea star was collected at Arcachon (France)/ the A.O (axial organ) was excised

with pinces and passed or not in antibiotics (peni-streptomycin) according to the used method.

b)Nude mice were purchased by the CSEAL-CNRS Orléans.-La source

c)Mouse SP2 and MBL2 cells were cultured in our laboratory

d)Gene cloning in a cytomegalovirus (CMV) was done as seen in( figures 1 and 2), from the sea star Igkappa gene(3).It constitutes the « promoter » 
Following steps as plasmid realization in correlation with the promoter, plasmid amplifications, transfections (5) were performed.

A-375 human melanome cells, were used. They were transfected by plasmids, after electroporation, at time $\mathrm{t}=0$. (AMAXA process) (6) or by classical electroporation for U2oS cells and Hela cells. At time $\mathrm{t}=24 \mathrm{~h}$, Cell suspensions were put on slides.Observations were realized with an optical microscope or by spectrophoto metry.

Cloning in N-terminal pCMV-Tag3B (c-mic tag)/ BamH1-EcoR1

GGA TCC GGA GGA ATG CGTGGCAACATGGCGTCTCTATGGATGTTCTTCTT TGTCGTGGGGATAACTTTACAACGGAGTTTGGCGATTTACACGTTTCGCG AGCAACCGTCGGACACTAGCGCGTTGCAGGGGAGCACAGTGGTGCTTCAC TGCTCCGTTGAGCAGTACATAAACACCACGGCCATCGTTTGGTGGAGCCG TGACTCGGTCATCAGCCACAACAAAGACCTGAAACTGTCCAGTCTAAACA CCGACCAGCTCCAAAGGTACTCGATTTCAGGCGACGCATCTCGGGGGGAA TTCAACCTTAAAATAGTGAACTTTACCGCCACAGACGCCGCCAGTTACCG CTGTCAGATG TAA GAA TTC

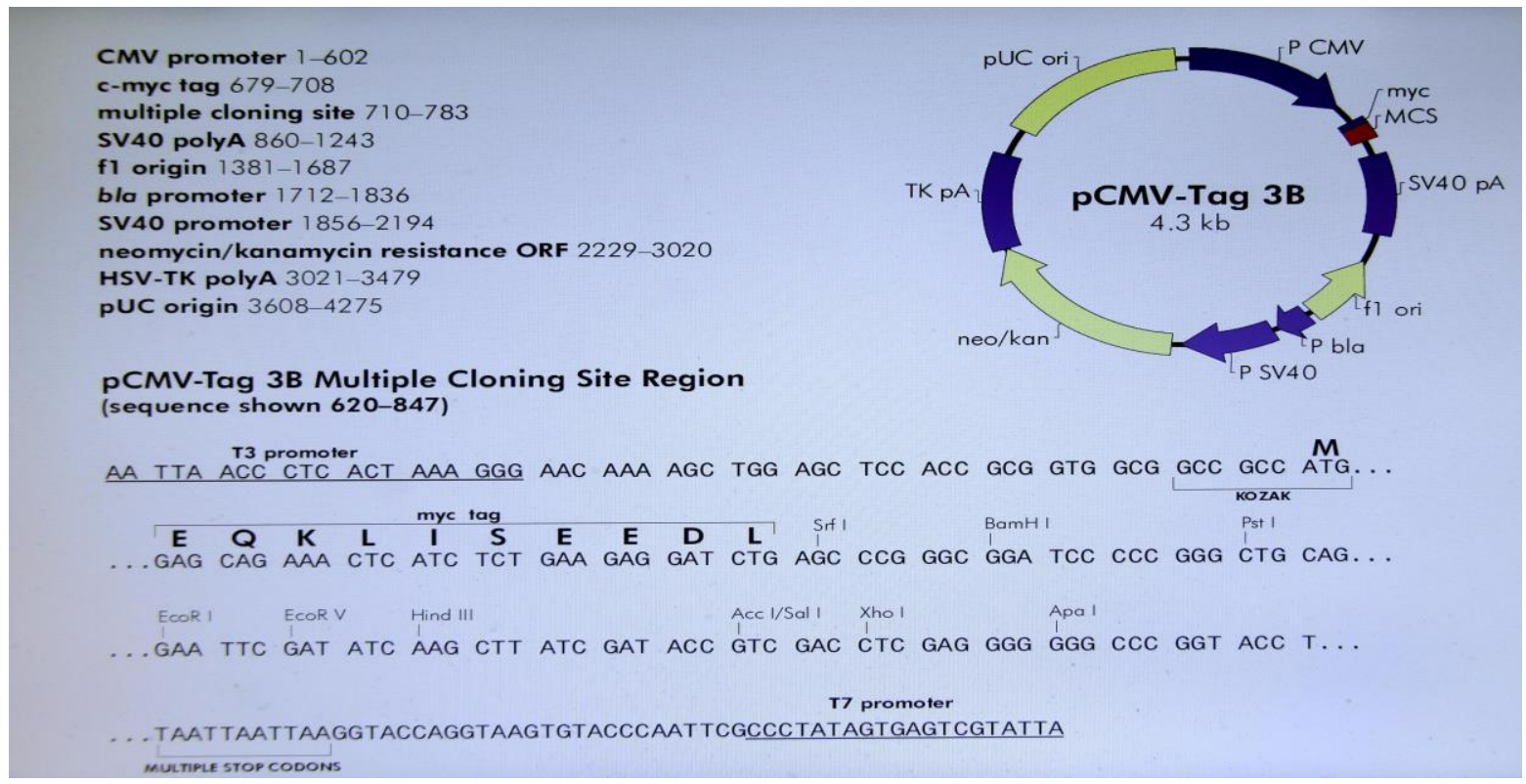

Figures 1 and 2. The pCMV-Tag 3B

\section{RESULTS}

1) In $50 \%$ of observed cases, human skin cancer heterotransplantationwas rejected by axial organ one in nude mouse:Extra- blood vessels were observed between the 2 heterotransplantations under the skin of the nude mouse. An antiserum (anti A.O cells) labelled many axial organ cells (mainly lymphocytes) which were surrounding cancerous human cells in the concerning heterotransplantation

2)In 30\% of observed cases, A.O cells exert an induced and spontaneous cytotoxicity against Mouse SP2 cells(2).

3)The protein «young », also named: invertebrate primitive antibody exert a spontaneous 
cytotoxicity 24 hours after transfection against A-375 melanome cells, U2oS cells and Hela cells. Percentages are expressed in figure 3.

$\begin{array}{rrr}\text { LYSIS: } \mathrm{A} 375 & \mathrm{U} 2 \mathrm{oS} & \text { Hela } \\ 100 \% & 100 \% & 70 \%\end{array}$

Figure 3. Lethality percentage, 24 hours after electroporation

Western blots do not confirm, the protein expression because of the high lethality of cancerous cells which is obtained ( The peak of the protein in western blots would be situated at 12.000 daltons).

Controls:A-375 cells, U2oS, Hela cells treated with alone electroporation show a weak lethality.

\section{CONCLUSION}

These results are of particular importance and show undoubtly that Axial organ cells from the Asterias rubens lymphoïd organ exert a spontaneous cytotoxicity, and, in certain cases, an induced cytotoxicity against Cancerous Vertebrate cells.

\section{REFERENCES}

Fen Chen et al. (2006). Mol. Cancer Ther. 5(1).

Flanagan, M. et al. (2011). Cancer Gene Ther. 18(8), 579-586.

Leclerc, M. et al. (1975). Transplantation, 74-76.

Luquet, G., \& Leclerc, M. (1983). Immunol.Lett. 6, 107-108.

Vincent, N. et al. (2014). 2, 320-322.

Leclerc, M., \& Otten, P. (2014). SAJ Biotechnology, 1, 104.

\section{Copyrights}

Copyright for this article is retained by the author(s), with first publication rights granted to the journal. This is an open-access article distributed under the terms and conditions of the Creative Commons Attribution license (http://creativecommons.org/licenses/by/4.0/). 